\title{
Shades of Springsteen
}





\section{Shades of \\ Springsteen}

POLITICS, LOVE, SPORTS,

AND MASGULINITY

$\vartheta$

John Massaro

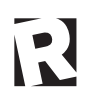

R U T GERS U NIVERSITY PRESS

New Brunswick, Camden, and Newark, New Jersey, and London 
Names: Massaro, John, 1941- author.

Title: Shades of Springsteen: politics, love, sports, and masculinity / John Massaro.

Description: New Brunswick: Rutgers University Press, 2021. | Includes bibliographical references and index.

Identifiers: LCCN 2020043439 | ISBN 9781978816169 (paperback) | ISBN 9781978816176 (cloth) | ISBN 9781978816183 (epub) | ISBN 9781978816190 (mobi) | ISBN 9781978816206 (pdf)

Subjects: LCSH: Springsteen, Bruce-Criticism and interpretation. | Rock musicPolitical aspects-United States.

Classification: LCC ML420.S77 M368 2021 | DDC 782.42166092 [B]—dc23

LC record available at https://lccn.loc.gov/2020043439

A British Cataloging-in-Publication record for this book is available from the British Library.

Copyright () 2021 by John Massaro

All rights reserved

No part of this book may be reproduced or utilized in any form or by any means, electronic or mechanical, or by any information storage and retrieval system, without

written permission from the publisher. Please contact Rutgers University Press, 106 Somerset Street, New Brunswick, NJ 08901. The only exception to this prohibition is "fair use" as defined by U.S. copyright law.

(2) The paper used in this publication meets the requirements of the American National Standard for Information Sciences-Permanence of Paper for Printed Library Materials, ANSI Z39.48-1992.

www.rutgersuniversitypress.org

Manufactured in the United States of America 
"I work to be an ancestor. I hope my summation will be written by my sons and daughters, with our family's help, and their sons and daughters with their guidance."

-Bruce Springsteen, Born to Run (2016a, 503)

To my descendants:

Kyler Massaro (24)

Kobi Massaro (21)

Grady Massaro Roy (15)

Eli Massaro Roy (14)

Jasper Massaro Roy (9)

Marlo Harry Massaro (6)

Remi John Massaro (4)

and beyond ...

—John Massaro, December 1, 2019 
